\title{
Identification of Soil Properties and Organophosphate Residues From Agricultural Land in Wanasari Sub-District, Brebes, Indonesia
}

\author{
Tri Joko ${ }^{1,2,}$, Sutrisno Anggoro ${ }^{1,3}$, Henna Rya Sunoko ${ }^{1,4}$, and Savitri Rachmawati ${ }^{2}$ \\ ${ }^{1}$ Doctorate Program of Environmental Science, School of Postgraduate Studies, Diponegoro University, Semarang -Indonesia \\ ${ }^{2}$ Majoring of Environmental Health, Public Health Faculty, Diponegoro University, Semarang - Indonesia \\ ${ }^{3}$ Faculty of Fisheries and Marine Science, Diponegoro University, Semarang - Indonesia \\ ${ }^{4}$ Faculty of Medicine, Diponegoro University, Semarang - Indonesia
}

\begin{abstract}
Organophosphates have been used to eradicate pests and prevent losses from harvest failures caused by pest attack. It is undeniable that the organophosphate persist in soil. This study aims to identify the organophosphate residue and soil properties include $\mathrm{pH}$, soil texture, and permeability. The soil samples were taken from cropland in 10 villages, Wanasari sub-district, Brebes, Indonesia. Organophosphate residue determined by gas chromatography using Flame Photometric Detector. Soil texture was determined by soil texture triangle from NRCS USDA, and the permeability value was determined by falling head method. The mean value of chlorpyrifos, profenofos, diazinon were $0.0078 ; 0.0388 ; 0.2271 \mathrm{mg} / 1$ respectively. The soil texture varies from clay, silt clay, loam, silt loam, and silt clay loam with permeability value at $10^{-7}$ with the soil $\mathrm{pH}$ value between $6.4-8.1$. The results showed that organophosphate residues found in the soil and its potential affect the soil fertility decline. We recommend to conduct routine soil quality analys is to prevent soil damage in the agricultural environment.
\end{abstract}

\section{Introduction}

Agriculture is a potential sector in Indonesia. Total agricultural land in Indonesia reaches $8,114,829$ ha in 2014. Central Java Province is the region with the second largest agricultural area after East Java province, with an area of 966,647 Ha. The area of agricultural land is also proportional to the production of food crops and horticulture in Indonesia. As a tropical country various types of plants can grow fertile, one of them is onion. Brebes Regency located in Central Java Province is a central area of onion. Onion production in Brebes Regency in 2014 reached 3,759,742 Kw, an average production of $121.46 \mathrm{Kw} / \mathrm{Ha}$. Wanasari District as the region with the highest onion production in Brebes Regency is able to produce $1,025,680 \mathrm{Kw}$, the average production is $144.97 \mathrm{Kw} /$ ha [1]. According to previous research conducted by Joko T, et al (2017) that onion farmers in Kecamatan Wanasari use large amounts of pesticides, and average to apply pesticides every three or four days. The use of pesticides in large numbers is due to onion plants are very vulnerable to pests, so farmers must apply insecticides to prevent damage to the plant. In his research, Joko T, et al (2017) showed that found farmers who use insecticides class of organophosphates with chlorpyrifos active ingredients [2].

Large and massive applications of organophosphate pesticides can cause adverse effects such as environmental pollution. The results of previous studies conducted Gafar et al. (2012) also showed that there was a decrease in soil parameters tested during addition of organophosphate pesticides. This research was conducted to find out the residue of organophosphate pesticide in soil and to know soil properties assessed through $\mathrm{pH}$ parameter, permeability, and soil texture [3].

\section{Material and methods}

\subsection{Organophosphorus residue test method}

The principle of testing the residual organophosphate is to use extraction with acetone. The extract was evaporated until it was almost dry and the residue was dissolved in n-Hexane. Generally no cleaning is required, and set by gas chromatography using an FPD detector. Reactors used are Acetone, Sodium Sulphate, $\mathrm{n}$-Hexan, and Celiite 545. Equipment used is shaker, evaporator, gohch cup, round flask, gourd flask, erlenmayer, and gas chromatograph equipped with FPD detector. The extraction procedure is carried out by weighing 50 grams of soil samples, inserting into the Erlenmeyer covered sharpening, then adding $100 \mathrm{ml}$ of acetone. The extracted results were filtered using a goblet plate that had been given celitte 545 pulp, and the sieve was then dried using a evaporator (evaporated). The residue present in the circular flask is diluted using $\mathrm{n}$-Hexane as much as $8 \mathrm{ml}$. To remove the water content 
in the sample, insert $\pm 2 \mathrm{~g}$ of anhydrous Sodium Sulphate into a round flask. Next n- Hexane is poured into test tube and implements up to $10 \mathrm{ml}$ volume. Determination of residue is done by injecting 1-2 $\mu$ l of extract into gas chromatograph. The calculation is performed by comparing the mooring time and the height or peak area of the chromatogram obtained from the sample solution and the reference standard solution.

\subsection{Permeability determination method}

Standart Procedure / Method used measurements with changing voltages (Variable Falling Head). The equipment used is glass tube pipette, silent $1.47 \mathrm{~cm}$ with an area of $1.696 \mathrm{~cm} 2$, brass tube samples, weight $=525$ gr, diameter $=6,36 \mathrm{~cm}$ and height $9,60 \mathrm{~cm}$, glass bottom tube weighing $175 \mathrm{gr}, 5,9 \mathrm{~cm}$ and $9.85 \mathrm{~cm}$. A brief description of the implementation of the sample is printed with a tube ring and weighed, tube rings containing soil samples soaked for 24 hours, tube rings mounted on permeability devices (top and bottom of samples given sample paper), after the sample is assembled. And it is observed whether it has entered the entire sample and is closed by the bottom, and the reading begins after positioning the water level in a glass guide glass zero (0) and the tap is opened. The results of the investigation were analyzed using laboratory seepage (k) values in $\mathrm{cm} / \mathrm{second}$.

\subsection{Soil texture determination method and $\mathrm{pH}$}

The method used is hydrometer. Equipment used is measuring cup $1000 \mathrm{ml}$ diameter $6.5 \mathrm{~cm}$, container hydrometer, thermometer, mixer, a set filter, scales, oven, stopwatch. The test procedure was carried out by wasting soil samples with dry weight \pm 50 grams with $100 \mathrm{mg}$ of aquades and $25 \mathrm{~mm}$ waterglass. Stirred until smooth and soaked \pm 24 hours, after 24 hours the mixture is dimixed \pm 15 minutes then transferred in a measuring cup and added aquades until the mixture becomes $1000 \mathrm{ml}$. The mouth of the tube is tightly closed with the palm of the hand, then shake in the horizontal direction \pm 1 minute after being shaken the tube carefully and stopwatch pressed. The scale number is read on $1 / 2,1$, and 2 then carefully lifted the float, washed with distilled water and inserted in a tube containing distilled water. The hydrometer buoy is inserted, the hydrometer is read at 5, 15, 20 minutes, 1.4 and 24 hours after each reading is washed and returned the hydrometer buoy into distilled water, the mixed temperature is measured once in the first 15 minutes then each subsequent reading, after reading Last transferred to filter no. 200 was washed until the washing water was clear and left the water flowing out. Items left on the filter no. 200 in dry, filtered and weighed. The results obtained in the form of graphs in the logarithmic scale show the percentage of fineness of the grains on the vertical axis with the grain of the soil on the horizontal axis.

\section{Result and discussion}

Organophosphate insecticides are hydrocarbon compounds containing one or more phosphate atoms and these phosphates have relatively short residence times in biological systems. Many organophosphate pesticides disappear from the soil within weeks after application [4]. If in this study found several types of organophosphate residues, then this shows the truth that farmers sprayed pesticides organophosphate continuously in amounts that exceed the recommended limits.

Organophosphate residues are found almost in all sample sites, except in the Pebatan village. Chlorpyrifos as a group of organophosphates is an insecticide which is found almost in all sampling sites. This is consistent with the results of this study showed that chlorpyrifos are the most widely used pesticides by farmers. Chlorpyrifos residue with the highest level of $0.0630 \mathrm{ppm}$ in Tanjungsari village, while the lowest residual content of $0.0014 \mathrm{ppm}$ was found in Klampok village (Figure 1, Table 1).

Other organophosphate group pesticides found were diazinon with levels of $0.0388 \mathrm{ppm}$ in Sigentong village. Organophosphate residues contain active metidation with levels of $0.0140 \mathrm{ppm}$ was found in the village of Sisalam. The organophosphate residue of profenofos was found in the village of Sigentong with levels of 0.1829 ppm and in the village of Klampok of $0.2714 \mathrm{ppm}$. The residual organophosphate type of malathion was found in four villages, namely Tanjungsari village with residual content of 0.1370 , Sisalam village with content of $0.1450 \mathrm{ppm}$, Dukuhwringin with residual malathion $0,3630 \mathrm{ppm}$, and Wanasari with residual content of 0.1490 ppm (Table 1).

Based on the result of organophosphate residue test on soil sample can be known pattern of insecticide usage that farmer tends to use 1-3 kinds of certain insecticide. Farmers in Tanjungsari village, Dukuhwringin, Wanasari apply insecticide type of malation and chlorpyrifos, Sisalam village apply insecticide type metidation, malation, and chlorpyrifos. Farmers in the village of Sigentong use kind of diazinon and chlorpyrifos. While the village of Jagalempeni, Pesantunan, Klampok, Siasem, Siwungkuk, and Tegalgandu applying the type clorpyrifos on their onion farm (Table 1).

Clorpyrifos and Diazinon are phosphorothioates compounds that have greater hydrolylic stability under aqueous conditions. Diazinon is a more active insecticide. Malation is a compound of phosphorodithioates [4].

In this study also measured the value of soil $\mathrm{pH}$, soil permeability, and soil texture at the sampling site. Laboratory test results showed that soil $\mathrm{pH}$ values ranged from 6.4 to 8.1 with the lowest $\mathrm{pH}$ value of 6.4 in soil samples in Sigentong and Pesantunan villages, then the highest $\mathrm{pH}$ value was 8.1 in the soil samples in Tanjungsari village. The soil permeability across the sample ranged from $3.848 \times 10^{-7}$ to $9.240 \times 10^{-7}$. The soil permeability value $<10-6$ is clay type with practically impervious properties (impermeable) (Table 1). 


\section{Organophosphate Residue Found in Soil Samples (ppm)}

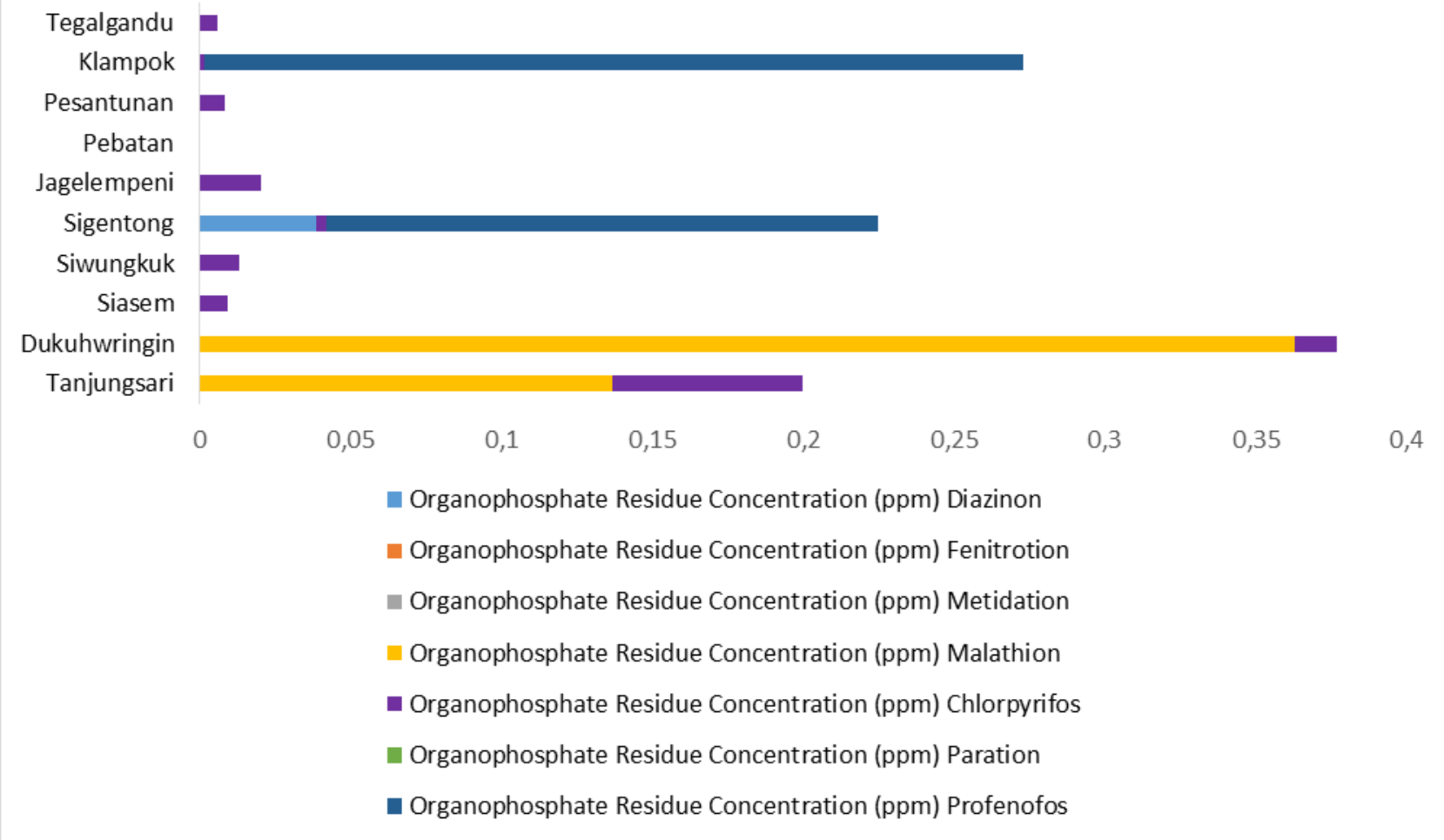

Fig. 1. Graphic of Organophosphate Residue in Distributed Sampling

Table 1 . Soil Properties and Organophosphate Residue Level

\begin{tabular}{|c|c|c|c|c|c|c|c|c|c|c|c|}
\hline \multirow[t]{2}{*}{ No } & \multirow{2}{*}{$\begin{array}{l}\text { Sampling } \\
\text { Location }\end{array}$} & \multicolumn{7}{|c|}{ Organophosphate Residue Concentration (ppm) } & \multirow{2}{*}{$\begin{array}{c}\mathrm{pH} \\
\mathrm{H}_{2} \mathrm{O}\end{array}$} & \multirow{2}{*}{$\begin{array}{c}\text { Soil } \\
\text { Permeability } \\
(\mathrm{cm} / \mathrm{s})\end{array}$} & \multirow{2}{*}{$\begin{array}{l}\text { Soil } \\
\text { Textur } \\
\text { e }\end{array}$} \\
\hline & & Diazinon & $\begin{array}{c}\text { Fenitro } \\
\text { tion }\end{array}$ & $\begin{array}{c}\text { Metidati } \\
\text { on }\end{array}$ & $\begin{array}{l}\text { Malathi- } \\
\text { on }\end{array}$ & $\begin{array}{l}\text { Chlorpyr } \\
\text { i-fos }\end{array}$ & Paration & $\begin{array}{c}\text { Profenof } \\
\text { os }\end{array}$ & & & \\
\hline 1. & Tanjungsari & $<\mathrm{LOD}$ & $<\mathrm{LOD}$ & $<\mathrm{LOD}$ & 0,1370 & 0,0630 & $<\mathrm{LOD}$ & $<\mathrm{LOD}$ & 8,1 & $7,708 \times 10^{-7}$ & Clay \\
\hline 2. & $\begin{array}{l}\text { Dukuhwringi } \\
\mathrm{n}\end{array}$ & $<$ LOD & $<\mathrm{LOD}$ & $<\mathrm{LOD}$ & 0,3630 & 0,0140 & $<\mathrm{LOD}$ & $<\mathrm{LOD}$ & 6,7 & $7,920 \times 10^{-7}$ & $\begin{array}{l}\text { Silt } \\
\text { loam }\end{array}$ \\
\hline 3. & Siasem & $<$ LOD & $<\mathrm{LOD}$ & $<\mathrm{LOD}$ & $<$ LOD & 0,0091 & $<\mathrm{LOD}$ & $<$ LOD & 7,3 & $3,848 \times 10^{-7}$ & $\begin{array}{l}\text { Silt } \\
\text { clay }\end{array}$ \\
\hline 4. & Siwungkuk & $<\mathrm{LOD}$ & $<$ LOD & $<$ LOD & $<$ LOD & 0,0130 & $<\mathrm{LOD}$ & $<$ LOD & 7,6 & $3,848 \times 10^{-7}$ & $\begin{array}{l}\text { Silt } \\
\text { loam }\end{array}$ \\
\hline 5. & Sigentong & 0,0388 & $<$ LOD & $<$ LOD & $<$ LOD & 0,0033 & $<$ LOD & 0,1829 & 6,4 & $4,613 \times 10^{-7}$ & $\begin{array}{l}\text { Sandy } \\
\text { clay } \\
\text { loam }\end{array}$ \\
\hline 6. & Jagelempeni & $<$ LOD & $<$ LOD & $<$ LOD & $<$ LOD & 0,0202 & $<$ LOD & $<$ LOD & 7,0 & $3,954 \times 10^{-7}$ & $\begin{array}{l}\text { Silt } \\
\text { clay }\end{array}$ \\
\hline 7. & Pebatan & $<$ LOD & $<\mathrm{LOD}$ & $<$ LOD & $<$ LOD & $<$ LOD & $<$ LOD & $<$ LOD & 7,5 & $3,848 \times 10^{-7}$ & $\begin{array}{l}\text { Silt } \\
\text { clay } \\
\text { loam }\end{array}$ \\
\hline 8. & Pesantunan & $<\mathrm{LOD}$ & $<\mathrm{LOD}$ & $<\mathrm{LOD}$ & $<\mathrm{LOD}$ & 0,0084 & $<\mathrm{LOD}$ & $<\mathrm{LOD}$ & 6,4 & $3,954 \times 10^{-7}$ & Loam \\
\hline 9. & Klampok & $<\mathrm{LOD}$ & $<$ LOD & $<\mathrm{LOD}$ & $<$ LOD & 0,0014 & $<$ LOD & 0,2714 & 7,8 & $9,240 \times 10^{-7}$ & Dust \\
\hline 10. & Tegalgandu & $<$ LOD & $<$ LOD & $<\mathrm{LOD}$ & $<$ LOD & 0,0061 & $<\mathrm{LOD}$ & $<\mathrm{LOD}$ & 7,2 & $7,708 \times 10^{-7}$ & $\begin{array}{l}\text { Silt } \\
\text { clay } \\
\text { loam }\end{array}$ \\
\hline
\end{tabular}


The result showed that residue with the highest level of Malathion $(0,3630 \mathrm{ppm})$ in Dukuhwringin village was found in soil $\mathrm{pH} 6.7$ and silt loam soil type (Table 1). J H. Huddleston (1996) has mentioned that there are several factors causing pesticide contamination on soil properties of the soil, properties of the pesticides, hydraulic loading on the soil, and crop management practise [5]. Land that has a property to transmit pesticides is quickly referred to as sensitive soils. Factors that affect the sensitivity of soil properties are permeability, water table conditions, organic matter content, and clay content. In this case, soil permeability can control leaching potential. Lands that have high leaching potential tend to be more sensitive than those with low leaching potential. While the organic matter and clay content can control the potential sorption of the soil. Soil that has low sorption potential will be more sensitive to contamination compared to soils that have high sorption potential.

Soils that have a very soft texture such as clay have very small pores and have very low permeability. While the soil with loam texture, silt loams, and clay loam have intermediate rates of soil permeability. Clay content has very small and flat particles that have a large surface area. This condition makes the surface of the soil is chemical reactive. The soil that has clay cotent is higher then the soil has a number of binding to the pesticide [5]. The soil sample in Tanjungsari village is clay type, and found two types of pesticide namely malathion and chlorpyrifos. Clay soil type is a low sensitivities soil because this soil is a group of slow or very slor permeabilities $\left(7,708 \times 10^{-7} \mathrm{~cm} / \mathrm{s}\right.$ in this sampling location) and high sorption potentials. The soil sample in Dukuhwringin village also found two types of pesticide malathion and chlorpyrifos on the silt loam type of soil, this type of soil is a group of moderate sensitivities, because it has slow permeabilities and relatively high sorption potentials. So also with the location of sampling which type of soil silt clay like in the village of Siasem and Jagalempeni.

Research conducted by Fosu-Mensah et al also found residuals of chlorpyrifos and profenofos in soil samples on cultivated cocoa farms in Ghana [6]. Supriyadi et al also conducted a study to determine the presence of organophosphate residues in agricultural land located in mojogedang, karanganyar central java province. The results show the residue of profenofos found on horticultural farms. In his research, also found soil texture and $\mathrm{pH}$ is the nature of soil that correlation is close to the residue of organophosphate in the soil. PH $\mathrm{H}_{2} \mathrm{O}$ in horticultural soil sample is 5.7 and sandy clay type of soil. In this study, the soil $\mathrm{pH}$ of the ten test samples ranged from 6.4 to 8.1 [7].

In this study found residual chlorpyrifos found almost in all sampling sites, unlike other types of pesticides are only found in one or two sampling sites only. The use of chlorpyrifos pesticides can affect the soil quality. It has been found that the use of chlorpyrifos can reduce the bacteria reinforcing aerob dinitrogen and dinitrogen fixation. Chlorpyrifos also significantly decreased the activity of acids and alkaline phosphatase and dehydrogenase, but the condition recovered after 14 days without the use of chlorpyrifos [8]. Farmers in Kecamatan Wanasari use intensive pesticides in large quantities, especially chlorpyrifos. It is also evident in almost all sampling sites found residual chlorpyrifos.

Based on E. P. Lichtenstein and Schulz (2014) that most insecticides are in dry soil, whereas insecticides are not present in high water soils [9]. The results of laboratory studies showing the degradation of chlorpyrifos insecticides have been done by Yucel et al. The results showed that for a $50 \%$ reduction in chlorpyrifos insecticide levels it took 10 days. This reason also shows that after application of insecticide chlorpyrifos as well as other types of organophosphates make residues still found in the soil as in the results of this study [10].

\section{Conclusion}

Soil texture was determined by soil texture triangle from NRCS USDA, and the permeability value was determined by falling head method. The mean value of chlorpyrifos, profenofos, diazinon were $0.0078 ; 0.0388$; $0.2271 \mathrm{mg} / \mathrm{l}$ respectively. The soil texture varies from clay, silt clay, loam, silt loam, and silt clay loam with permeability value at $10^{-7}$ with the soil $\mathrm{pH}$ value between 6.4-8.1. The results showed that organophosphate residues found in the soil and its potential affect the soil fertility decline. We recommend to conduct routine soil quality analysis to prevent soil damage in the agricultural environment.

\section{References}

1. BPS. 2014. Luas Lahan Sawah Menurut Provinsi (ha), 2003-2014. [online] https://www.bps.go.id/linkTableDinamis/view/id/89 5.Accessed on July, 182017

2. T. Joko, S. Anggoro, H. R. Sunoko, and S. Rachmawati, Applied and Environmental Soil Science, (2017). Article ID 5896191

3. M.O. Gafar, Journal of Agricultural Science and Soil Science (ISSN.2251 - 0044) vol. 2(2) pp058062-2012, (2012).

4. S. U. Khan, Pesticides in the soil environment. Elsevier, (2016)

5. J.H. Huddleston. 1996. How soil properties affect groundwater vulnerability to pesticide contamination. EM 8599. Oregon State University.

6. B. Y. Fosu-Mensah, E. D. Okoffo, G. Darko, and C. Gordon, Environmental Systems Research, 5 (1), 10, (2016)

7. S. Supriyadi, A. D. Utami, H. Widijanto, and S. Sumani, Modern Applied Science, 9 (6), 87, (2015)

8. C. Pozo, M. V. Martinez, Toledo, V. Salmeron, B. Rodelas, and J. Gonzalez Lopez, Environmental Toxicology and Chemistry, 14 (2), 187-192, (1995) 
9. E. P. Lichtenstein, and K. R. Schulz, Journal of Economic Entomology, 57 (5), 618-627, (2014)
10. U. Yucel, M. Ylim, K. Gozek, C. S. Helling, and Y. Sarýkaya, Journal of Environmental Science \& Health Part B, 34(1), 75-95, (1999) 